\title{
Contributions of health technologies in risk assessment for suicide behavior: an integrative review
}

\author{
Contribuições das tecnologias em saúde na avaliação de risco para comportamento suicida: revisão integrativa
}

Contribuciones de las tecnologías sanitarias a la evaluación de riesgos de la conducta suicida: una revisión integradora

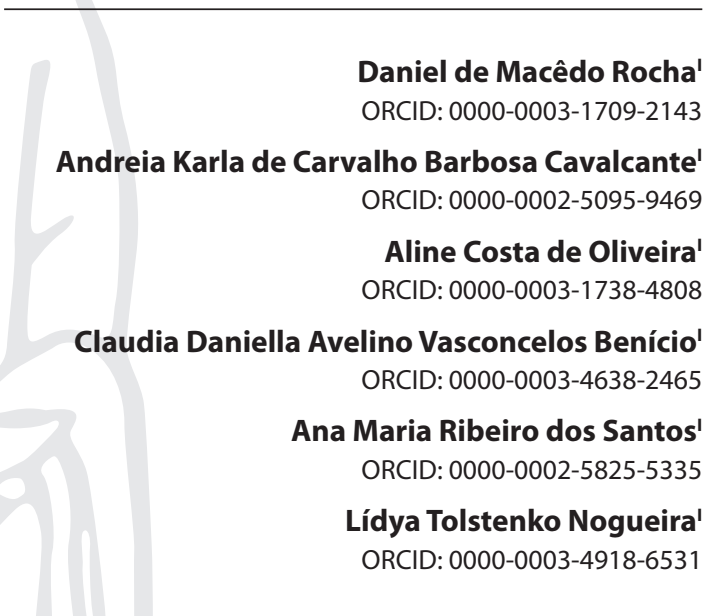

' Universidade Federal do Piauí. Teresina, Piauí, Brazil.

How to cite this article: Rocha DM, Cavalcante AKCB, Oliveira AC, Benício CDAV Santos AMR, Nogueira LT. Contributions of health technologies in risk assessment for suicide behavior: an integrative review. Rev Bras Enferm. 2021;74(Suppl 3):e20200205. doi: http://dx.doi.org/10.1590/0034-7167-2020-0205

Corresponding author: Daniel de Macêdo Rocha E-mail:daniel_m.rocha@outlook.com.br

EDITOR IN CHIEF: Dulce Barbosa ASSOCIATE EDITOR: Álvaro Sousa

Submission: $03-28-2020$

Approval: 09-20-2020

\begin{abstract}
Objective: to identify how health technologies contribute to risk assessment for suicidal behavior. Methods: an integrative review carried out on the MEDLINE, CINAHL, Web of Science, SCOPUS, LILACS and BDENF databases. The sample consisted of 12 primary studies, with no temporal or language delimitation. Analysis of results occurred descriptively. Results: the technologies included assistance and teaching aspects favorable to data screening, monitoring and navigation, capable of predicting individual, biological, clinical, psychological, environmental and social markers for suicidal behavior. Thus, measurement scale, software and computational algorithms constituted valid and sensitive instruments for improving performance, expanding skills and knowledge, good care practices, effective communication and assistance planning. Conclusion: the identified technologies proved to be effective in identifying risk states for suicidal behavior, representing effective resources for directing care and necessary interventions.

Descriptors: Suicide; Suicide, Attempt; Risk Measurement; Technologies; Nursing.
\end{abstract}

\section{RESUMO}

Objetivo: identificar como as tecnologias em saúde contribuem na avaliação de risco para o comportamento suicida. Métodos: revisão integrativa realizada nas bases MEDLINE, CINAHL, Web of Science, SCOPUS, LILACS e BDENF. A amostra foi constituída por 12 estudos primários, sem delimitação temporal ou de idioma. A análise dos resultados ocorreu de forma descritiva. Resultados: as tecnologias contemplaram aspectos assistenciais e de ensino favoráveis ao rastreio, monitoramento e navegação de dados, capazes de prever marcadores individuais, biológicos, clínicos, psicológicos, ambientais e sociais para o comportamento suicida. Desse modo, escala de medida, softwares e algoritmos computacionais constituíram instrumentos válidos e sensíveis para melhoria de desempenho, ampliação de habilidades e conhecimentos, boas práticas de cuidados, comunicação efetiva e planejamento assistencial. Conclusão: as tecnologias identificadas se mostraram eficazes para identificação de estados de risco para comportamento suicida, representando recursos efetivos por direcionar o atendimento e as intervenções necessárias.

Descritores: Suicídio; Tentativa de Suicídio; Medição de Risco; Tecnologias; Enfermagem.

\section{RESUMEN}

Objetivo: identificar cómo las tecnologías sanitarias contribuyen a la evaluación del riesgo de conducta suicida. Métodos: revisión integradora realizada en las bases de datos MEDLINE, CINAHL, Web of Science, SCOPUS, LILACS y BDENF. La muestra estuvo formada por 12 estudios primarios, sin delimitación temporal ni lingüística. El análisis de los resultados se realizó de forma descriptiva. Resultados: las tecnologías incluyeron aspectos asistenciales y didácticos favorables al rastreo, monitoreo y navegación de datos, capaces de predecir marcadores individuales, biológicos, clínicos, psicológicos, ambientales y sociales de la conducta suicida. Así, la escala de medición, el software y los algoritmos computacionales fueron instrumentos válidos y sensibles para mejorar el desempeño, expandir habilidades y conocimientos, buenas prácticas de atención, comunicación efectiva y planificación de la asistencia. Conclusión: las tecnologías identificadas demostraron ser efectivas en la identificación de estados de riesgo de conducta suicida, representando recursos efectivos para dirigir la atención y las intervenciones necesarias.

Descriptores: Suicidio; Intento de Suicidio; Medición de Riesgo; Tecnologías; Enfermería. 


\section{INTRODUCTION}

Suicidal behavior is a universal and preventable public health problem, as it has high incidence and mortality indicators, making it the fifteenth leading cause of death in the population and the second most frequent among adolescents and young adults ${ }^{(1)}$. Considered a complex and multidimensional phenomenon, the expression of behavior involves ideation, planning, attempt and consummated suicide, being understood as a deliberate and intentional act, initiated and executed by a person who has a clear notion or strong expectation that the outcome will be fatal ${ }^{(2-3)}$.

Estimates made by the World Health Organization show that approximately 800 thousand people commit suicide per year and that Brazil follows global parameters. Assistance limitations and underreporting contribute to making the practice effective, generating individual, collective, social, economic and health impacts due to the potential years of life lost, the epidemic character and the need to reorganize comprehensive care lines aimed at enhancing life ${ }^{(2-4)}$.

Thus, the repercussions associated with behavior correspond to compromise of the different dimensions that constitute health and quality of life, since it still represents stigma and social taboo. This behavior is related to care dependence, occupational limitation, abandonment of educational activities and social isolation both by patients and family members who also present psychosocial changes, whether in the process of rehabilitation or during the experience of mourning, becoming a risk for events of the same nature ${ }^{(1,5)}$.

Understanding suicidal behavior has become multidisciplinary, and the high indicators are associated with deficiencies in public mental health policies as well as the lack of technologies that present clinical guidelines and recommendations for directing care, identification, assessment and risk classification, appropriate treatment, need for support and social support ${ }^{(6)}$.

In Brazil, even referring to the need for strategies to promote quality of life and care management, most scientific investigations focus on identifying mortality coefficients, epidemiological profile and possible associated factors. It is shown that the interaction between individual, environmental, social, cultural, physiological, genetic and biological aspects contributes to behavior and determines risk states ${ }^{(7-8)}$.

In nursing, health technologies are promising methods, capable of guiding care and educational practices, favoring welcoming, care planning, definition of clinical conduct, monitoring of risk conditions and assessment of results and performance. These are products or processes that allow the involvement of professionals and that result in the expansion of knowledge, attitudes and skills to optimize the work process and improve quality of service $e^{(9-10)}$.

It is noteworthy that, despite the structuring of prevention programs, the initiatives for early identification of risk in different contexts are still not very expressive and show the need for integration between the different devices that make up Psychosocial Care Networks (RAPS - Redes de Atenção Psicossocial) and the foundation of care in effective, integrated, sustainable and evidence-based strategies ${ }^{(11)}$.

Considering the need for technological instruments capable of predicting and determining the degree of vulnerability to suicide and directing public policies and assistance strategies for prevention and control, studies that seek to investigate the contributions of health technologies in identifying risk states are fundamental and favor comprehensive care with quality and safety.

\section{OBJECTIVE}

To identify how health technologies contribute to risk assessment for suicidal behavior.

\section{METHODS}

\section{Type of study}

This is an integrative review of the literature based on the theoretical framework proposed by Whittemore and Knafl, structured in six stages of investigation: elaboration of the research question; literature search and sampling; definition of the information to be extracted from the selected studies; critical assessment of the included studies; interpretation of results; synthesis of knowledge; review presentation ${ }^{(12)}$.

\section{Methodological procedures}

Using the domains of the acronym PICo, this investigation included studies that focused on Problem suicidal behavior, Interest, risk assessment and Context, health technologies ${ }^{(13)}$. Thus, this study was conducted based on the following question: what are the contributions of health technologies in assessment of risk for suicidal behavior?

The bibliographic survey was carried out between the months of September and December 2019 through consultation of the electronic databases Medical Literature Analysis and Retrieval System online (MEDLINE via PubMed ${ }^{\circ}$ ), Cumulative Index to Nursing and Allied Health Literature (CINAHL- Ebsco), Web of Science ${ }^{\mathrm{TM}}$, SCOPUS, Latin American \& Caribbean Literature in Health Sciences (LILACS) and Nursing Database (BDENF) via Virtual Health Library.

To make the search operational, controlled and uncontrolled descriptors were selected after consulting the Health Sciences Descriptors (DeCS-Descritores em Ciências da Saúde), Medical Subject Headings (MESH) and List of Headings vocabularies from CINAHL Information Systems. The combination was performed using the Boolean operators OR and AND. Chart 1 presents the descriptors, as well as the strategy adopted in MEDLINE, which maintained the same search standardization for the other databases consulted.

Primary source studies that presented technology developed to identify, assess or measure suicidal behavior risk, without language or time limits were included. Reviews, editorials, theses, dissertations and studies in which the outcome did not prioritize the application of technological instruments to predict or manage risk situations were excluded. Duplicate articles were considered only once, prioritizing specific health and nursing bases, followed by multidisciplinary.

The search was carried out by two reviewers independently, who, after standardization of terms and intersections, operationalized the search, reading titles, abstracts and inclusion, obtained an agreement rate greater than $80 \%$. Disagreements were managed by the third reviewer, who issued an opinion for decision on inclusion. In order to recover production, access 
was made through the periodical portal of the Coordination for the Improvement of Higher Education Personnel (Coordenação de Aperfeiçoamento de Pessoal de Nível Superior) in an area with Internet Protocol (IP), recognized at Universidade Federal do Piauí. Moreover, the retrieved references were imported into Endnote Web management, aiming to sort, identify and delete duplicate records between different databases.

Chart 1 - Controlled and non-controlled descriptors used to operationalize the search (in Portuguese, English and Spanish), 2020

\begin{tabular}{|c|c|c|}
\hline \multicolumn{3}{|r|}{ Health Sciences Descriptors } \\
\hline \multirow[b]{2}{*}{$\mathbf{P}$} & Controlled & Suicídio; Tentativa de Suicídio; Ideação Suicida \\
\hline & $\begin{array}{l}\text { Non- } \\
\text { controlled }\end{array}$ & $\begin{array}{l}\text { Suicídios; Parassuicídio; Comportamento Suicida; } \\
\text { Suicidio; Suicide; Ideación Suicida; Ideas Suicidas; } \\
\text { Suicidal Ideation; Ideations, Suicidal; Intento de } \\
\text { Suicidio; Suicide, Attempted; Attempted Suicide; } \\
\text { Parasuicide }\end{array}$ \\
\hline \multirow[b]{2}{*}{$\mathbf{I}$} & Controlled & Medição de Risco \\
\hline & $\begin{array}{l}\text { Non- } \\
\text { controlled }\end{array}$ & $\begin{array}{l}\text { Análise de Risco; Avaliação de Risco; Avaliação } \\
\text { de Risco para a Saúde; Determinação do Risco; } \\
\text { Classificação de Risco; Medición de Riesgo; Análisis de } \\
\text { Riesgo; Evaluación de Riesgo; Evaluación de Riesgo } \\
\text { para la Salud; Risk Assessment; Assessment, Health } \\
\text { Risk; Assessment, Risk; Assessments, Health Risk; } \\
\text { Health Risk Assessment; Risk Assessments }\end{array}$ \\
\hline \multirow[b]{2}{*}{ Co } & Controlled & Tecnologia \\
\hline & $\begin{array}{l}\text { Non- } \\
\text { controlled }\end{array}$ & $\begin{array}{l}\text { Sistema Tecnológico; Tecnologias e Aplicativos de } \\
\text { Software; Tecnología; Tecnología y Aplicaciones de } \\
\text { Software; Technological System; Technologies and } \\
\text { Software Applications; Technologies; Technology; } \\
\text { Technology and Software Applications }\end{array}$ \\
\hline \multicolumn{3}{|c|}{ Medical Subject Headings and list CINAHL } \\
\hline \multirow[b]{2}{*}{$\mathbf{P}$} & Controlled & Suicide; Suicidal Ideation; Suicide, Attempted \\
\hline & $\begin{array}{l}\text { Non- } \\
\text { controlled }\end{array}$ & $\begin{array}{l}\text { Suicides; Ideation, Suicidal; Ideations, Suicidal; } \\
\text { Suicidal Ideations; Attempted Suicide; Parasuicide; } \\
\text { Parasuicides }\end{array}$ \\
\hline \multirow[b]{2}{*}{ I } & Controlled & Risk Assessment \\
\hline & $\begin{array}{l}\text { Non- } \\
\text { controlled }\end{array}$ & $\begin{array}{l}\text { Assessments, Risk; Risk Assessments; Health Risk } \\
\text { Assessment; Assessment, Health Risk; Health } \\
\text { Risk Assessments; Risk Assessment, Health; Risk } \\
\text { Assessments, Health; Assessment, Risk }\end{array}$ \\
\hline \multirow[b]{2}{*}{ Co } & Controlled & Technology \\
\hline & $\begin{array}{c}\text { Non- } \\
\text { controlled }\end{array}$ & $\begin{array}{l}\text { Technology; Technologies; Technologies and } \\
\text { Software Applications }\end{array}$ \\
\hline \multicolumn{3}{|r|}{ P AND I AND Co } \\
\hline \multicolumn{3}{|c|}{ 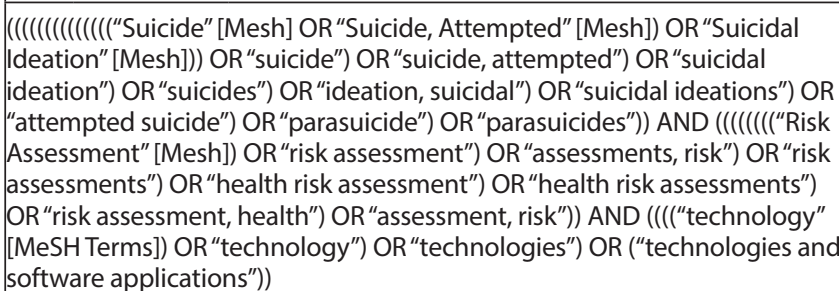 } \\
\hline
\end{tabular}

The search totaled 196 studies, and, after applying the eligibility criteria, a sample of 12 articles was obtained. The path taken for identification, selection, eligibility, inclusion and sample followed the Preferred Reporting Items for Systematic Reviews and MetaAnalyzes (PRISMA) ${ }^{(14)}$ recommendations, as shown in Figure 1.

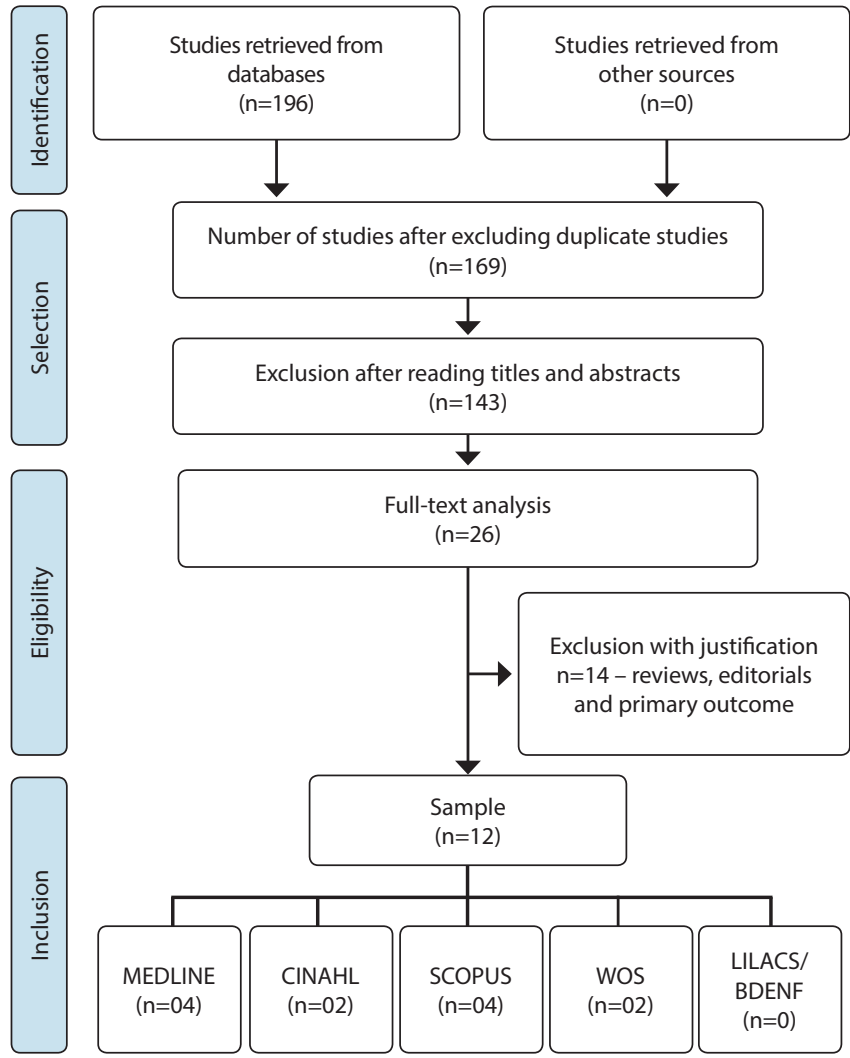

Figure 1 - Selection path of primary studies on the investigated bases, 2020

\section{Data analysis and collection}

Data extraction was performed with the aid of a validated and adapted instrument, including variables related to identification of studies, methodological aspects (design and quality of evidence), technology assessed, as well as its objective, limitations, main results and conclusions ${ }^{(15)}$.

Evidence quality was assessed by Grades of Recommendation, Assessment, Development and Evaluation (GRADE), which can be characterized as high, moderate, low or very low. For classification, the following criteria were considered: study design, risk of bias, inconsistency, uncertainty if the evidence is direct, inaccuracy and other considerations ${ }^{(16)}$.

Analysis of evidence and synthesis of results were carried out descriptively, in two thematic categories, according to the assistance and educational technologies identified.

\section{RESULTS}

The results showed randomized clinical trials and observational studies that supported the construction, development and assessment of tools capable of predicting individual, biological, clinical, psychological, environmental and social markers that indicate a risk for suicidal behavior. Most of them were published in English and between 1995 and 2019 (17-28).

The analyzed technologies included assistance (83.3\%) $)^{(17-23,25-27)}$ and teaching $(25 \%)^{(21,24,28)}$ aspects, presenting a favorable application to risk screening and monitoring, as well as navigation and data storage. Thus, measurement scale ${ }^{(20)}$, software/computational 
algorithms ${ }^{(17-19,21-22,24-27)}$ and learning tools $s^{(21,24,28)}$ were included, described as valid, specific, objective and sensitive instruments for risk management ${ }^{(18-28)}$.

Despite having limitations, the technological resources analyzed contributed to improving performance, expanding knowledge, skills and abilities, good care practices, effective communication, care planning, specialized care and effective interventions. Still, other positive effects were verified in the reduction of the time of attendance and in the application in different contexts and levels of health care ${ }^{(18-28)}$.

Chart 2 presents the distribution and synthesis of the included studies according to the identified technology, its objectives and limitations, applicability, main results, conclusions and level of evidence.

Evidence quality was determined to be moderate (Chart 3), which suggests moderate confidence in the effect estimated by the assessed results. The limitations presented in conducting and describing the studies contributed to bias risk and were decisive for reducing evidence quality.

\section{DISCUSSION}

Recognizing suicidal behavior as a public health problem, associated with the globalization process, favored developing technologies with the potential for prevention, identification, monitoring and risk classification, as well as for directing care practices and clinical conduct in different contexts and levels of care ${ }^{(17-28)}$.

In this study, we highlight the growing interest of researchers in the international literature to seek resources capable of guiding care and educational practices based on the early identification of people at risk of suicide and the assessment of the interaction between predisposing factors. Thus, the first technology was developed in 1995, showing the ability to manage care because it considers that different conditions can generate losses in physical, mental and social health and contribute to risky behaviors ${ }^{(21)}$.

Despite the predominance of methodological studies developed to support the construction, assessment and validation of measurement instruments and tools ${ }^{(17-21)}$, we verified other

Chart 2 - Synthesis of the studies included in terms of assistance and teaching technologies used in risk management for suicidal behavior, 2020

\begin{tabular}{|c|c|c|c|c|}
\hline \multicolumn{5}{|c|}{ Category 1 - Assistance technologies used in risk management for suicidal behavior } \\
\hline Technology and objective & Applicability & Main results & Conclusion & Limitation \\
\hline $\begin{array}{l}\text { HelPath }^{(17)} \text { (Computational } \\
\text { platform) } \\
\text { Subsidizing screening and } \\
\text { directing to specialized } \\
\text { services according to the risk } \\
\text { situation. }\end{array}$ & $\begin{array}{l}\text { Screening and } \\
\text { monitoring }\end{array}$ & $\begin{array}{l}\text { Device based on cognitive- } \\
\text { behavioral therapy, which } \\
\text { favored prevention from the } \\
\text { emotional state. It enabled risk } \\
\text { management and supported } \\
\text { clinical decision and information } \\
\text { recording for surveillance } \\
\text { purposes. }\end{array}$ & $\begin{array}{l}\text { Easy to use and support tool for } \\
\text { clinical decision and monitoring } \\
\text { of patients at risk, indication of } \\
\text { treatment and follow-up actions. }\end{array}$ & $\begin{array}{l}\text { It did not assess } \\
\text { results of the } \\
\text { technological } \\
\text { implantation. }\end{array}$ \\
\hline $\begin{array}{l}\text { Mobile-assisted treatment }{ }^{(25)} \\
\text { Assessing the impact of an } \\
\text { application on depression } \\
\text { and suicide risk. }\end{array}$ & Monitoring & $\begin{array}{l}\text { It favored the reduction of } \\
\text { self-reported suicide risk. There } \\
\text { were no differences between } \\
\text { groups regarding the symptom } \\
\text { of depression. }\end{array}$ & $\begin{array}{l}\text { The technology reduced the } \\
\text { immediate risk of suicide, but } \\
\text { did not influence the level of } \\
\text { depression experienced, indicating } \\
\text { that other therapeutic resources } \\
\text { are needed. }\end{array}$ & $\begin{array}{l}\text { The results were } \\
\text { generalized to the } \\
\text { adult population. }\end{array}$ \\
\hline $\begin{array}{l}\text { Natural language } \\
\text { processing } \\
\text { OurDataHelps.org } \\
\text { Estimating suicide risk } \\
\text { through combined analysis } \\
\text { of social media, demographic } \\
\text { and mental conditions. }\end{array}$ & $\begin{array}{l}\text { Screening and } \\
\text { data navigation }\end{array}$ & $\begin{array}{l}\text { Automated resource that can } \\
\text { be performed by untrained } \\
\text { professionals and that has shown } \\
\text { feasibility and accuracy to predict } \\
\text { quantifiable signs of suicidal } \\
\text { behavior. }\end{array}$ & $\begin{array}{l}\text { It was the basis for screening, } \\
\text { crisis prevention, improvement of } \\
\text { clinical systems and care. }\end{array}$ & $\begin{array}{l}\text { Ethical and privacy } \\
\text { implications. } \\
\text { Application by } \\
\text { individual consent. }\end{array}$ \\
\hline $\begin{array}{l}\text { Linehan Suicide Safety } \mathrm{Net}^{(18)} \\
(\text { LSSN) } \\
\text { Assessing, managing, and } \\
\text { documenting suicide risk. }\end{array}$ & $\begin{array}{l}\text { Monitoring and } \\
\text { data navigation }\end{array}$ & $\begin{array}{l}\text { Web-based multimedia tool } \\
\text { that increased confidence in } \\
\text { risk management, assessment } \\
\text { and management, representing } \\
\text { a method to improve clinical } \\
\text { interventions. }\end{array}$ & $\begin{array}{l}\text { The high acceptability shows that } \\
\text { this tool is promising for assessing } \\
\text { and managing suicide risk. }\end{array}$ & $\begin{array}{l}\text { There is no evidence } \\
\text { of effectiveness in } \\
\text { different cultures. }\end{array}$ \\
\hline $\begin{array}{l}\text { e-PASS Suicidal Ideation } \\
\text { Detector (eSID)(19) } \\
\text { Identifying suicidal ideation } \\
\text { in Primary Health Care. }\end{array}$ & $\begin{array}{l}\text { Screening and } \\
\text { data navigation }\end{array}$ & $\begin{array}{l}\text { Fast, effective, low cost method } \\
\text { with the potential to improve the } \\
\text { quality of care. It performed well } \\
\text { among adults and the elderly of } \\
\text { both genders. }\end{array}$ & $\begin{array}{l}\text { ESID has been configured as a } \\
\text { precise and favorable method for } \\
\text { identification and assessment of } \\
\text { risk states. }\end{array}$ & $\begin{array}{l}\text { Only the medical } \\
\text { performance was } \\
\text { assessed, not } \\
\text { considering the } \\
\text { other essential } \\
\text { categories for risk } \\
\text { assessment. }\end{array}$ \\
\hline $\begin{array}{l}\text { Computational algorithm } \\
\text { Identifying markers of } \\
\text { suicidal thinking in linguistic } \\
\text { and acoustic characteristics } \\
\text { (dynamics, frequency and } \\
\text { vocal quality). }\end{array}$ & $\begin{array}{l}\text { Screening and } \\
\text { data navigation }\end{array}$ & $\begin{array}{l}\text { Objective, precise and useful tool } \\
\text { to determine the level of suicidal } \\
\text { intention, directing prevention } \\
\text { and treatment in different } \\
\text { contexts and environments. }\end{array}$ & $\begin{array}{l}\text { A technology with potential for } \\
\text { application in school, youth and } \\
\text { community environments was } \\
\text { evidenced, favoring the early } \\
\text { identification of behavior. }\end{array}$ & $\begin{array}{l}\text { Technological } \\
\text { performance has } \\
\text { not been assessed in } \\
\text { other populations. }\end{array}$ \\
\hline
\end{tabular}




\begin{tabular}{|c|c|c|c|c|}
\hline \multicolumn{5}{|c|}{ Category 1 - Assistance technologies used in risk management for suicidal behavior } \\
\hline Technology and objective & Applicability & Main results & Conclusion & Limitation \\
\hline $\begin{array}{l}\text { Momentary ecological } \\
\text { assessment } \\
\text { Classifying and recognizing } \\
\text { situations of risk related to } \\
\text { mood, self-harm, environment } \\
\text { and social context. }\end{array}$ & $\begin{array}{l}\text { Screening and } \\
\text { monitoring }\end{array}$ & $\begin{array}{l}\text { Instrument based on computational } \\
\text { monitoring, considered valid, } \\
\text { viable and with a high acceptance } \\
\text { rate, which enabled advances } \\
\text { in identification of predisposing } \\
\text { factors for behavior. }\end{array}$ & $\begin{array}{l}\text { Potential to support the study of } \\
\text { suicide risk, the assessment and } \\
\text { monitoring of cognitive states and } \\
\text { associated psychosocial factors. }\end{array}$ & $\begin{array}{l}\text { Technological } \\
\text { accuracy may be } \\
\text { reduced when } \\
\text { the algorithm is } \\
\text { applied to different } \\
\text { navigation routes. }\end{array}$ \\
\hline $\begin{array}{l}\text { Momentary ecological } \\
\text { assessment }{ }^{(23)} \\
\text { Predicting individual } \\
\text { changes, clinical factors and } \\
\text { risk states. }\end{array}$ & $\begin{array}{l}\text { Screening and } \\
\text { monitoring }\end{array}$ & $\begin{array}{l}\text { Predictive model, with high } \\
\text { sensitivity and accuracy to } \\
\text { identify ideation, leading to } \\
\text { the planning of preventive } \\
\text { interventions. }\end{array}$ & $\begin{array}{l}\text { It made it possible to improve } \\
\text { identification, assessment and } \\
\text { intervention in high-risk states, } \\
\text { in addition to management of } \\
\text { chronic and recurrent disorders. }\end{array}$ & $\begin{array}{l}\text { It allows assessment } \\
\text { in a single condition } \\
\text { related to suicidal } \\
\text { behavior (ideation). }\end{array}$ \\
\hline $\begin{array}{l}\text { Suicide Ideation Scale }{ }^{(20)} \\
\text { Identifying and classifying } \\
\text { suicide risk. }\end{array}$ & Screening & $\begin{array}{l}\text { Specificity, sensitivity of } \\
\text { measurement, simplicity of } \\
\text { administration, clinical and } \\
\text { research applications. }\end{array}$ & $\begin{array}{l}\text { The scale showed adequate } \\
\text { psychometric properties to identify } \\
\text { suicidal thoughts. }\end{array}$ & $\begin{array}{l}\text { It does not include } \\
\text { variables related to } \\
\text { individual suicide } \\
\text { history. }\end{array}$ \\
\hline $\begin{array}{l}\text { Software - Lifenet }{ }^{(21)} \\
\text { Determining suicide risk in } \\
\text { adolescents, identify predictors, } \\
\text { and point out interventions. }\end{array}$ & Screening & $\begin{array}{l}\text { Accuracy in determining risk } \\
\text { situations, reducing service time, } \\
\text { improving data collection and } \\
\text { recording. }\end{array}$ & $\begin{array}{l}\text { It presented organizational, clinical } \\
\text { and legal impacts when assessing } \\
\text { risks using psychological and } \\
\text { behavioral indicators. }\end{array}$ & $\begin{array}{l}\text { There is no evidence } \\
\text { of validity and } \\
\text { external reliability. }\end{array}$ \\
\hline \multicolumn{5}{|c|}{ Category 2 - Teaching technologies in risk assessment for suicidal behavior } \\
\hline $\begin{array}{l}\text { Electronic health education } \\
\text { system }{ }^{(24)} \\
\text { Improving skills for } \\
\text { assessment and care for } \\
\text { adults at risk of suicide. }\end{array}$ & $\begin{array}{l}\text { Screening, data } \\
\text { navigation and } \\
\text { storage }\end{array}$ & $\begin{array}{l}\text { Increased confidence and } \\
\text { knowledge from the multiple } \\
\text { approach involving education } \\
\text { and technology. It favored good } \\
\text { practices, documentation and care } \\
\text { planning. }\end{array}$ & $\begin{array}{l}\text { It resulted in the best performance } \\
\text { for assessing suicide and was } \\
\text { part of the team at all levels of } \\
\text { performance. }\end{array}$ & $\begin{array}{l}\text { No limitation has } \\
\text { been described. }\end{array}$ \\
\hline $\begin{array}{l}\text { Clinical simulation }{ }^{(28)} \\
\text { Developing and applying } \\
\text { interactive virtual patient for } \\
\text { risk assessment for suicide. }\end{array}$ & Screening & $\begin{array}{l}\text { The contributions expressed } \\
\text { an improvement in knowledge, } \\
\text { communication skills and } \\
\text { performance for risk assessment. }\end{array}$ & $\begin{array}{l}\text { Resource with potential for } \\
\text { higher education and permanent } \\
\text { education activities. }\end{array}$ & $\begin{array}{l}\text { It requires material } \\
\text { and financial } \\
\text { resources to } \\
\text { guarantee the realism } \\
\text { of the clinical scenario. }\end{array}$ \\
\hline $\begin{array}{l}\text { Software - } \text { Lifenet }^{(21)} \\
\text { Determining suicide risk by } \\
\text { identifying predictors. }\end{array}$ & $\begin{array}{l}\text { Screening, data } \\
\text { navigation and } \\
\text { storage }\end{array}$ & $\begin{array}{l}\text { Improved knowledge and skills } \\
\text { as well as constituting a data } \\
\text { repository and clinical assessments. }\end{array}$ & $\begin{array}{l}\text { It presented properties favorable } \\
\text { to the consistent assessment of } \\
\text { patients at risk. }\end{array}$ & $\begin{array}{l}\text { There is no evidence } \\
\text { of external validity. }\end{array}$ \\
\hline
\end{tabular}

Chart 3 - GRADE assessment, 2020

\begin{tabular}{|c|c|c|c|c|c|c|c|}
\hline \multicolumn{7}{|c|}{ Quality assessment } & \multirow[t]{2}{*}{ Quality } \\
\hline $\mathbf{N}$ & Design & Bias risk & Inconsistency & $\begin{array}{c}\text { Uncertainty } \\
\text { if evidence is } \\
\text { indirect }\end{array}$ & Inaccuracy & $\begin{array}{c}\text { Other } \\
\text { considerations }\end{array}$ & \\
\hline \multicolumn{8}{|c|}{ Assistance technologies used in risk management for suicidal behavior } \\
\hline 10 & $\begin{array}{l}\text { Randomized } \\
\text { clinical trial (3) } \\
\text { Observational (7) }\end{array}$ & High* $^{*}$ & No serious inconsistency & $\begin{array}{l}\text { No important } \\
\text { indirect evidence }\end{array}$ & No serious inaccuracy & None & Moderate \\
\hline \multicolumn{8}{|c|}{ Teaching technologies in risk assessment for suicidal behavior } \\
\hline 3 & $\begin{array}{l}\text { Randomized } \\
\text { clinical trial (1) } \\
\text { Observational (2) }\end{array}$ & $\mathrm{High}^{*}$ & No serious inconsistency & $\begin{array}{l}\text { No important } \\
\text { indirect evidence }\end{array}$ & No serious inaccuracy & None & Moderate \\
\hline
\end{tabular}

Caption: $N$ - Number of studies included in the assessed outcome. ${ }^{*}$ Risk of bias in randomized controlled trials related to blinding absence and allocation of participants.

relevant designs for clinical nursing practice. Among them is a randomized clinical trial, which allows establishing cause and effect relationships, gathering evidence capable of supporting care with safety, efficacy and quality ${ }^{(25,27-28)}$, and observational, which demands less time and cost, being constantly used to indicate prognosis and assess risk exposure results ${ }^{(22-24)}$.

Thus, in the midst of individual, social and cultural challenges, as well as deficiencies in public health policies, we identified technologies with evidence of validity, sensitivity, precision that prioritized suicide prevention through screening, case monitoring, registration, data navigation and storage. Still, they proved to be effective in reducing the attendance time and to subsidize teaching practices, leading to planning, execution and accompanying learning, as well as the construction and reconstruction of knowledge ${ }^{(17-28)}$.

\section{Assistance technologies used in risk management for suicidal behavior}

Considering that the early identification of suicidal behavior risk is associated with the reduction of mortality indicators and 
the improvement of referrals and care interventions, we included different assistive technologies that had positive impacts on the level of awareness about the phenomenon and that supported

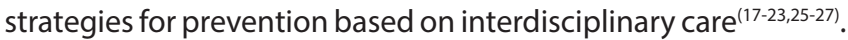

The construction and assessment of computerized tools such as software and computational algorithms predominated in the study, constituting a constant target for clinical investigations and presenting potential for application in screening programs, risk monitoring and data navigation ${ }^{(17-19,21-23,25-26)}$. Digital resources can be expressed by mobile applications, platforms and operating systems, being evident in health services due to their ability to reach a wider audience, as well as to arouse professional interest and manage assistance quickly and organized, constituting as an indicator of quality, processes and results ${ }^{(29)}$.

Among the technologies identified, softwares LSSN, Lifenet and HelPath showed evidence of viability and sensitivity for caring for patients with suicidal behavior, due to assessment and monitoring of risky behaviors, the recording of information and professional advice for necessary interventions, favoring access to security plans and support for crisis situations ${ }^{(17-18,21)}$.

In nursing practice, implementing care based on technological methods for preventing suicide is an innovative method and represents a tool that facilitates systematization, care management and the work process. It leads to embracement, measurement of risks based on modifiable determinants, valuation of subjectivity and individual needs, planning of comprehensive and multidimensional assistance, health matrix and assessment of preventive, diagnostic and therapeutic actions ${ }^{(30-31)}$.

The complex nature of suicide required developing technologies that combined individual, psychological, social and environmental markers to be assessed, being verified in two studies that used momentary ecological assessment to predict risk conditions ${ }^{(23,27)}$. This resource has been widely applied in health practices, to assess behaviors, point out the need for support and predict factors that contribute to greater vulnerability such as mood states, self-harm, sociodemographic, mental and clinical conditions ${ }^{(32)}$.

In the current scenario, contingency plans adopted to control the COVID-19 pandemic and to dissolve the epidemic curve have led to changes in social, economic, political and health contexts. Thus, there was an increase in suicide indicators and the need for technological incorporation in care practices to protect mental health and promote psychosocial well-being. Therefore, different stressors related to financial instability, consumption of psychoactive substances, transmission of false information or without scientific evidence and domestic violence become prevalent, indicating risk states for vulnerable populations ${ }^{(33)}$.

It is noteworthy that, associated with these conditions, the difficulties faced to access specialized services during the period of social distance resulting from the COVID-19 pandemic are constant, favoring development, intensification and recurrence of psychiatric disorders, which constitute the main factor associated with suicidal behavior. Thus, it becomes essential to provide digital alternatives that allow risk assessment, screening and monitoring, and effective interventions to stabilize predisposing conditions $^{(23,33)}$.

The assessment of social media, despite being marked by ethical, cultural and privacy implications, also suggested clinical utility and feasibility for screening and implementing prevention strategies. These are automated natural language processing techniques that have quantitatively estimated suicide risk through analysis of interactions, behaviors, posts and statements made outside the health services. Aspects related to past behavior, combating stigma or discrimination in mental disorders and supporting people in a similar situation indicated a situation of vulnerability ${ }^{(23,27)}$.

Social networks represent widespread tools, which have changed the forms of interaction, by allowing users to create and share content that values, encourages or condemns suicide. In this regard, they can be easily accessed by vulnerable people and lead to excessive exposure of intimacy, increased perception of the success of others, procrastination, dissatisfaction with body image, lack of criticism and reflection that can affect levels of anxiety and depression, contributing to the higher risk ${ }^{(34-35)}$.

Developing technology aimed at specific populations such as adolescents and young adults reflects the need for specialized care, adaptation of care and assistance strategies ${ }^{(21)}$. In the literature, this population segment presents a higher risk for suicide, being associated with psychological, physical and social changes, movements of extreme independence, periods of contradictions, conflicts and ambivalences, formation of personal identity, emotional instabilities and predisposition to psychoactive substance abuse ${ }^{(36-38)}$.

However, new resources are needed to assess signs of psychological distress in elderly people, since the indicators of anxiety, depression and suicide are expressive in this population segment. Thus, developing technological resources for assessment of psychological conditions, identification of risk states and valuation of protective factors in the elderly population is still incipient, becoming a gap in knowledge and a target strategy for future scientific investigations.

Another technological tool highlighted the need and the possibility of integration between the different levels of health care, such as the primary, having a positive effect on performance for screening suicidal ideation ${ }^{(19)}$. Mental health strategies in primary care and their articulation with the other devices that make up RAPS are a challenging reality in the Brazilian scenario, in which clinical pathologies are prioritized, either due to the lack of knowledge, experiences, skills or stigmatization of people with disorders mental ${ }^{(39)}$.

The scientific literature considers that managing risk situations and identifying psychological, social and cultural conditions represent strategies to be initiated in primary care, which constitute an important care resource, as they present competencies for health promotion actions and comprehensive care based on control and prevention measures ${ }^{(40)}$.

In other countries, primary care valuation demonstrates a significant reduction in the indicators related to suicide through identification of predisposing factors for behavior, performance in different community environments and elaboration of an action plan based on protection measures and promotion of mental health in social reintegration and in expanding access to psychiatric care ${ }^{(41)}$.

Measurement scales were also identified, representing common practice in health services to classify risk conditions and identify 
associated factors. In this context, Suicide Ideation Scale showed specificity, reliability and sensitivity in assessing the presence and intensity of suicidal ideation, indicating the degree of intention, attitudes and determinants related to behavior ${ }^{(20)}$.

Using measurement scales and management tools has demonstrated validity and reliability favorable to clinical practice, health assessment and search for evidence, when associated with other therapeutic resources, exercising direct influence on care decisions, care interventions, formulation of health programs and institutional policies ${ }^{(42)}$.

Therefore, we consider that, despite the limitations evidenced, the technological approach presents potentialities for the care of patients at risk of suicide, constituting themselves as a supportive resource for safe, comprehensive and quality care. Still, it represents a method for formulating public policies, reflecting greater access to mental health services, cost reduction and indicators related to the problem.

\section{Teaching technologies in risk assessment for suicidal behavior}

Assistance to patients with suicidal behavior is complex and requires, in addition to physical, human, structural, material and financial resources, development of competences, knowledge and skills necessary for early identification of risk and adequate management and meeting individual and collective needs.

In this sense, incorporating educational technologies into health practices was significant in the international literature. It was a necessary, relevant methodological alternative capable of modernizing teaching, providing professional empowerment and contributing to the establishment of safe, effective and humanized care strategies as a life-enhancing mechanism ${ }^{(21,24,28)}$.

Among the strategies applied in the teaching of screening, assessment and prevention of suicide, technologies aimed at higher education and permanent education activities, such as simulation, software and electronic system, were highlighted, based on the critical, creative and transforming perspective, described as possible instruments different contexts are employed. Still, they represented promising methods and facilitators of learning, for presenting quality results associated with active participation and search for professional autonomy ${ }^{(21,24,28)}$.

Clinical simulation, a resource widely associated with other educational techniques, was characterized by the structuring of realistic and precise scenarios that favored developing communication skills and performance assessment in the identification of risk states ${ }^{(28)}$. Defined as an interactive pedagogical tool that uses techniques to promote, improve or validate the participant's progression, the incorporation of simulators in health practices has grown, and the results suggest positive effects on developing reasoning and clinical competence, satisfaction and self-confidence for making decisions ${ }^{(43)}$.

For nursing education, the simulated practice can be adapted to individual needs, previous experiences and learning rhythms. It reflects in the promotion of patient safety through the improvement of skills to manage real situations, the improvement of performance in care techniques and professional performance based on comprehensive care and social responsibility ${ }^{(28,44)}$.
Regarding the insertion of electronic information and communication systems in teaching, practical methods for academic management were considered and favorable to better clinical performance, showing positive effects in increasing knowledge to identify risky behaviors, in data storage and sharing ${ }^{(24)}$.

Recognized as a tool that optimizes the care, teaching and research process, the computerized resources enable autonomous and independent learning, being related to the improvement of the quality of services, the capacity for leadership and teamwork based on the availability of interactive methods that make evidence-based practices effective ${ }^{(44)}$.

Including the Lifenet software in this category refers to learning opportunities that the technological application has shown and its ability to promote good care practices and planning of assistance strategies ${ }^{(21)}$.

In Brazil, developing educational programs mediated by technologies and the constant changes in curricular guidelines resulted in new ways of teaching and producing knowledge, influencing the work process and inducing changes in the various professional contexts. However, despite these advances, this review shows that teaching practices aimed at managing suicidal behavior are still limited, using mostly traditional resources that minimize active participation in the learning process ${ }^{(45)}$.

It should be noted that even with the potentialities shown, the technological instrumentalization of teaching has been challenging, making it essential to understand the mechanisms of action, available resources and socio-cultural contexts experienced. It is necessary to identify the best alternatives for integration with other educational activities and to recognize weaknesses for the purpose of improvement.

Therefore, teaching technologies developed for identification, risk assessment and prevention of suicide can directly reflect on professional training and the reduction of epidemiological indicators that configure it as a health problem. Moreover, they represent instruments capable of expanding skills, knowledge, attitudes and competences associated with better professional performance, best care practices and the optimization of the work process.

\section{Study limitations}

The limitation of this review refers to predominance of studies that justified the construction and technological assessment; however, they did not present evidence of validity for application in different populations and socio-cultural contexts.

\section{Contributions to nursing}

The evidence included in this review contributed to the synthesis of knowledge about health technologies used for screening, monitoring and teaching risk assessment of suicidal behavior. They pointed out valid, sensitive and capable care and educational alternatives to expand access to specialized services and to improve knowledge, self-confidence and professional performance for clinical decision-making, care management and effective suicide prevention and control strategies. Furthermore, they allowed to identify gaps in knowledge and unmet needs, 
such as the low development of resources, which allow identifying risk and valuing protective factors in the elderly population.

\section{CONCLUSION}

In this review, we identified assistive and educational technologies, such as software, computational algorithms, measurement scales and clinical simulation, favorable to screening, monitoring, teaching and preventing suicidal behavior and which represented valid, sensitive, effective and accurate alternatives for managing states risk.

We conclude that despite the limitations, the technological resources stand out as innovative tools and with high potential for identifying individual, biological, environmental, social, clinical and psychological markers. They are innovative for developing clinical knowledge, skills and competences that can contribute to performance improvement, assistance planning, adequate monitoring of risk behaviors, directing care and necessary interventions, good practices and the formulation of comprehensive care lines. Further investigations need to be conducted to assess the effect of technologies on measurement and management process risk, as well as to address all population groups vulnerable to suicide.

\section{FUNDING}

Conselho Nacional de Desenvolvimento Científico e Tecnológico - CNPq.

\section{REFERENCES}

1. Franklin JC, Ribeiro JD, Fox KR, Bentley KH, Kleiman EM, Huang X, et al. Risk factors for suicidal thoughts and behaviors: a meta-analysis of 50 years of research. Psychol Bull. 2017;143(2):187-232. doi: 10.1037/bul0000084

2. Cho SE, Geem ZW, Na KS. Prediction of suicide among 372,813 individuals under medical check-up. J Psychiatr Res. 2020;131:9-14. doi: 10.1016/j.jpsychires.2020.08.035

3. Goodfellow B, Kõlves K, Leo DD. Contemporary classifications of suicidal behaviors: a systematic literature review. Crisis. 2020;41(3):179-86. doi: 10.1027/0227-5910/a000622

4. World Health Organization (WHO). Preventing suicide: a resource for media professionals. Geneva, 2017.

5. Pitman A, Putri AK, Souza T, Stevenson F, King M, Osborn D, et al. The impact of suicide bereavement on educational and occupational functioning: a qualitative study of 460 bereaved adults. Int J Environ Res Public Health. 2018;15(4):643. doi: 10.3390/ijerph15040643

6. Yarborough BJH, Ahmedani BK, Boggs JM, Beck A, Coleman KJ, Sterling S, et al. challenges of population-based measurement of suicide prevention activities across multiple health systems. eGEMs. 2019;7(1):13. doi: 0.5334/egems.277

7. Cicogna JIR, Hillesheim D, Hallal ALLC. Mortalidade por suicídio de adolescentes no Brasil: tendência temporal de crescimento entre 2000 e 2015. J Bras Psiquiatr. 2019;68(1):1-7. doi: 10.1590/0047-2085000000218

8. Veloso LUP, Lima CLS, Sales JCS, Monteiro CFS, Gonçalves AMS, Silva Jr FJG. Suicidal ideation among health field undergraduates: prevalence and associated factors. Rev Gaúcha Enferm. 2019;40:e20180144. doi: 10.1590/1983-1447.2019.20180144

9. Kilbourne AM, Beck K, Rublee BS, Ramanuj P, O'Brien RW, Tomoyasu N. Measuring and improving the quality of mental health care: a global perspective. World Psychiatry. 2018;17(1):30-38. doi: 10.1002/wps.20482

10. Yancey NR. Technology and teaching-learning: opportunities and restrictions. Nurs Sci Q. 2018;31(4):333-4. doi: 10.1177/0894318418792880

11. Cescon LC, Capozzolo AA, Lima LC. Aproximações e distanciamentos ao suicídio: analisadores de um serviço de atenção psicossocial. Saude Soc. 2018;27(1):185-200. doi: 10.1590/s0104-12902018170376

12. Whittemore R, Knafl K. The integrative review: updated methodology. J Adv Nurs. 2005;52(5):546-53. doi: 10.1111/j.1365-2648.2005.03621.x

13. Lockwood C, Porrit K, Munn Z, Rittenmeyer L, Salmond S, Bjerrum M, et al. Chapter 2: systematic reviews of qualitative evidence. In: Aromataris E, Munn Z, editors. Joanna Briggs Institute, 2017 [cited Nov 07, 2019]. Available from: https://reviewersmanual.joannabriggs.org

14. Moher D, Liberati A, Tetzlaff J, Altman DG. Preferred Reporting Items for Systematic Reviews and MetaAnalyses: The PRISMA Statement. PLoS Med. 2009;6(6):e1000097. doi: 10.1371/journal.pmed.1000097

15. Marziale MH. Instrumento para recolección de datos revisión integrativa [Internet]. 2015 [cited 2019 Oct 15]. Available from: http:// gruposdepesquisa.eerp.usp.br/sites/redenso/wp-content/uploads/sites/9/2016/04/Instrumiento-revision-de-la-litetaruraRedENSO-2017.pdf

16. Schünemann H, Brożek J, Guyatt G, Oxman A. The GRADE Working Group. GRADE handbook for grading quality of evidence and strength of recommendations [Internet]. 2013[cited 2019 Oct 15]. Available from: www.guidelinedevelopment.org/handbook

17. Miranda JM, Palacios-Isaac A, López-Flores F, Martínez A, Aguilar H, Jiménez L, et al. Development of a computational platform to support the screening, surveillance, prevention and detection of suicidal behaviors. Lecture Notes of the Institute for Computer Sciences, Social-Informatics and Telecommunications Engineering. Proceddings [Internet]. 2019 [cited 2019 Dec 28];288:83-101. doi: 10.1007/978-3-030-25872-6_7

18. Harned MS, Lungu A, Wilks CR, Linehan MM. Evaluating a multimedia tool for suicide risk assessment and management: the Linehan Suicide Safety Net. J Clin Psychol. 2017;73(3):308-18. doi: 10.1002/jclp.22331 
19. Meyer D, Abbott JA, Rehm I, Bhar S, Barak A, Deng G, et al. Development of a suicidal ideation detection tool for primary healthcare settings: using open access online psychosocial data. Telemed J Educ Health. 2017;23(4):273-81. doi: 10.1089/tmj.2016.0110

20. Luxton DD, Rudd MD, Reger MA, Gahm GA. A psychometric study of the Suicide Ideation Scale. Arch Suicide Res. 2011;15(3):250-8. doi: $10.1080 / 13811118.2011 .589720$

21. Ferns WJ. Lifenet: a knowledge-based decision support tool for the risk assessment of adolescent suicide. Expert Syst Applic. 1995;9(2):16576. doi: 10.1016/0957-4174(94)00059-5

22. Pestian JP, Sorter M, Connolly B, Cohen KB, McCullumsmith C, Gee JT, et al. A machine learning approach to identifying the thought markers of suicidal subjects: a prospective multicenter trial. Suicide Life-Threatening Behav. 2017;47(1):112-21. doi: 10.1111/sltb.12312

23. Thompson WK, Gershon A, O'Hara R, Bernert RA, Depp CA. The prediction of study-emergent suicidal ideation in bipolar disorder: a pilot study using ecological momentary assessment data. Bipolar Disord. 2014;16(7):669-77. doi: 10.1111/bdi.12218

24. Ryan K, Tindall C, Strudwick G. Enhancing key competencies of health professionals in the assessment and care of adults at risk of suicide through education and technology. Clin Nurse Spec. 2017;31(5):268-75. doi: 10.1097/NUR.0000000000000322

25. O'Toole MS, Arendt MB, Pedersen CM. Testing an app-assisted treatment for suicide prevention in a randomized controlled trial: effects on suicide risk and depression. Behavior Ther. 2019;50(2):421-9. doi: 10.1016/j.beth.2018.07.007

26. Coppersmith G, Leary R, Crutchley P, Fine A. Natural language processing of social media as screening for suicide risk. Biomed Inform Insights. 2018;10:1-11. doi: 10.1177/1178222618792860

27. Husky M, Olie E, Guillaume S, Genty C, Swendsen J, Courtet P. Feasibility and validity of ecological momentary assessment in the investigation of suicide risk. Psychiatry Res. 2014;220(1-2):564-70. doi: 10.1016/j.psychres.2014.08.019

28. Foster A, Chaudhary N, Murphy J, Lok B, Waller J, Buckley PF. The use of simulation to teach suicide risk assessment to health profession trainees: rationale, methodology, and a proof of concept demonstration with a virtual patient. Acad Psychiatry. 2015;39(6):620-9. doi: 10.1007/s40596-014-0185-9

29. Báo ACP, Amestoy SC, Moura GMSS, Trindade LL. Indicadores de qualidade: ferramentas para o gerenciamento de boas práticas em saúde. Rev Bras Enferm. 2019;72(2):377-84. doi: 10.1590/0034-7167-2018-0479

30. Barrera A, Gee C, Wood A, Gibson O, Bayley D, Geddes J. Introducing artificial intelligence in acute psychiatric inpatient care: qualitative study of its use to conduct nursing observations. Evidence-based Mental Health. 2020;23(1):34-38. doi: 10.1136/ebmental-2019-300136

31. Campos DB, Bezerra IC, Jorge MSB. Tecnologias do cuidado em saúde mental: práticas e processos da Atenção Primária. Rev Bras Enferm. 2018;71(Suppl 5):2101-8. doi: 10.1590/0034-7167-2017-0478

32. Peters EM, Dong LY, Thomas T, Khalaj S, Balbuena L, Baetz M, et al. Instability of suicidal ideation in patients hospitalized for depression: an exploratory study using smartphone ecological momentary assessment. Arch Suicide Res. 2020;1-14. doi: 10.1080/13811118.2020.1783410

33. Gunnell D, Appleby L, Arensman E, Hawton K, John A, Kapur N, et al. Suicide risk and prevention during the COVID-19 pandemic. Lancet Psychiatry. 2020;7(6):468-471. doi: 10.1016/S2215-0366(20)30171-1

34. Parrott S, Britt BC, Hayes JL, Albright DL. Social media and suicide: a validation of terms to help identify suicide-related social media posts. J Evidence-Based Soc Work. 2020;17(5):624-634. doi: 10.1080/26408066.2020.1788478

35. Pourmand A, Roberson J, Caggiula A, Monsalve N, Rahimi M, Torres-Llenza V. Social media and suicide: a review of technology-based epidemiology and risk assessment. Telemed J Educ Health. 2019;25(10):880-8. doi: 10.1089/tmj.2018.0203

36. Cervantes CAD, Contreras ML. Suicide attempt in teenagers: associated factors. Rev Chilena Pediatr. 2019;90(6):606-16. doi: 10.32641/ rchped.v90i6.1012

37. Orri M, Scardera S, Perret LC, Bolanis D, Temcheff, C, Séguin JR, et al. Mental health problems and risk of suicidal ideation and attempts in adolescents. Pediatrics. 2020;146(1):e20193823. doi: 10.1542/peds.2019-3823

38. Siabato EFM, Mendoza, IXF, Camargo, YS. Asociación entre depresión e ideación suicida en un grupo de adolescentes colombianos. Pensamiento Psicol. 2017;15(1):51-61. doi: 10.11144/Javerianacali.PPSI15-1.ADIS

39. Rotoli A, Silva MRS, Santos AM, Oliveira AMN, Gomes GC. Mental health in Primary Care: challenges for the resoluteness of actions. Esc Anna Nery. 2019;23(2):e20180303. doi: 10.1590/2177-9465-ean-2018-0303

40. Sisler SM, Schapiro NA, Nakaishi M, Steinbuchel P. Suicide assessment and treatment in pediatric primary care settings. 2020;1-14. doi: $10.1111 /$ jcap. 12282

41. LeCloux AM, Weimer M, Culp SL, Bjorkgren K, Service S, Campo JV. The feasibility and impact of a suicide risk screening program in rural adult primary care: a pilot test of the ask suicide-screening questions toolkit. Psychosomat. 2020;3182(20)30140-7. doi: 10.1016/j.psym.2020.05.002

42. Georgiadou S, Pitsalidis K. Scales in suicide risk assessment. Hellenic J Nurs. 2020;59(1):47-52.

43. Padilha JM, Ribeiro A, Rosa J, Marques D, Machado PP. Clinical virtual simulation as lifelong learning strategy: nurse's verdict. Clin Simul Nurs. 2020;47:1-5. doi: 10.1016/j.ecns.2020.06.012

44. Bagherian B, Sabzevari S, Mirzaei T, Ravari A. Effects of technology on nursing care and caring attributes of a sample of Iranian critical care nurses. Intensive Crit Care Nurs. 2017;39:18-27. doi: 10.1016/j.iccn.2016.08.011

45. Pascon DM, Otrenti E, Mira VL. Percepção e desempenho de graduandos de enfermagem em avaliação de metodologias ativas. Acta Paul Enferm. 2018;31(1):61-70. doi: 10.1590/1982-0194201800010 